\title{
Bone Marrow Transplant Recipient
}

National Cancer Institute

\section{Source}

National Cancer Institute. Bone Marrow Transplant Recipient. NCI Thesaurus. Code C131759.

An individual receiving a bone marrow transplant. 